\title{
Aplikasi Penentuan Beban Sks Mengajar Dosen Pengampu Mata Kuliah
}

\author{
Gellysa Urva ${ }^{1}$, Ari Sellyana ${ }^{2}$ \\ 1,2Program Studi Teknik Informatika, Sekolah Tinggi Teknologi Dumai \\ Jl. Utama Karya Bukit Batrem II Dumai \\ e-mail: gellysa.urva@gmail.com
}

\begin{abstract}
ABSTRAK
Dosen merupakan penunjang penting dalam pendidikan perguruan tinggi yang melaksanakan tridharma perguruaan tinggi dengan beban mengajar paling sedikit 12 (dua belas) SKS dan paling banyak 16 (enam belas) SKS. Pembagian beban mengajar dosen merupakan kegiatan yang rutin dari akademik di Perguruan Tinggi yang selalu dilakukan dalam menghadapi semester baru serta memiliki peranan penting dalam pengelolaan suatu institusi perguruan tinggi dimana masalah pembagian beban mengajar dosen ini merupakan permasalahan kompleks yang menjadi bagian penting dari operasinya. Proses ini memerlukan banyak waktu, dan tenaga agar pembagian tugas mengajar sesuai dengan level kemampuan dosen dan pemerataan pembagian beban SKS mengajar Dosen. Dengan menumpuknya tugas administratif akademik di awal semester, maka dibutuhkan suatu aplikasi yang dapat mengotomatisasi pembagian beban mengajar dosen sehingga pembagian tugas dapat dilakukan dengan cepat. Aplikasi ini menerapkan metode algoritma genetika dimana solusinya dikodekan dalam rangkaian suatu objek yang teridiri dari bagian penentu jumlah SKS mengajar dosen. Setelah dilakukan implementasi dan pengujian, aplikasi dapat menghasilkan distribusi beban mengajar dosen dengan metode algoritma genetika berdasarkan input matriks kompetensi dosen dan mempertimbangkan kesesuaian kompetensi dosen sebagai pengampu.
\end{abstract}

Kata kunci: Aplikasi, Mata kuliah, Dosen

\section{ABSTRACT}

Lecturer is an important support in the college education that carry out high perguruaan with a load of tridharma teaching at least 12 (twelve) CREDITS and at most 16 (sixteen) SKS. The Division of the burden of teaching lecturer is a activity that routine from academic Colleges are always done in the face of the new semester as well as having an important role in the management of an institution of higher education where the issue of the Division of the burden of teaching professors this is a complex problem into an important part of its operations. This process requires a lot of time and energy, so that the Division of teaching task in accordance with the level of ability of the lecturer and equitable sharing of the burden of SKS teaching Lecturer. With a pile of academic administrative tasks at the beginning of the semester, then needed an application that can automate the sharing of the burden of teaching and lecturers so that the Division of tasks can be done quickly. The application of genetic algorithm in

UNITEX Vol 11 No.2 Juli - Desember 2018 | p-ISSN 2089-3957 | e-ISSN 2580-2585 
which the methods of applying the solution encoded in an object that contains a series of decisive part number of SKS teaching lecturer. After implementation and testing, the application can generate a teaching load distribution method of genetic algorithm with professors based on competency matrix lecturer input and consider the appropriateness of competence as lecturer pengampu.

Keywords: applications, courses, professors

\section{Pendahuluan}

Sebagaimana diamanatkan dalam UU Nomor 14 Tahun 2005 tentang Guru dan Dosen, Peraturan Pemerintah Republik Indonesia Nomor 37 Tahun 2009 tentang Dosen, disebutkan bahwa dosen adalah pendidik profesional dan ilmuwan dengan tugas utama mentransformasikan, mengembangkan dan menyebarluaskan ilmu pengetahuan, teknologi dan seni melalui pendidikan, penelitian dan pengabdian kepada masyarakat. Dosen merupakan penunjang penting dalam pendidikan perguruan tinggi yang melaksanakan tridharma perguruaan tinggi dengan beban kerja paling sedikit 12 (dua belas) SKS dan paling banyak 16 (enam belas) SKS. Sebagai sebuah institusi pendidikan tinggi, STT Dumai memiliki prosedur perencanaan proses belajar mengajar yang dilaksanakan setiap awal semester baru, yaitu:

1. Admin program studi (prodi) mengumpulkan data sumber daya, termasuk kurikulum, silabus, data dosen, data ruang, matriks kompetensi dosen dan rekapitulasi kompetensi.

2. Ketua Prodi melakukan analisis kebutuhan dengan ketersediaan sumber daya.

3. Apabila ketersediaan sumber daya tidak terpenuhi maka ketua prodi membuat list alternatif dosen luar biasa yang bisa diberdayakan.

4. Sebaliknya jika sumber daya terpenuhi maka prosedur selanjutnya yaitu ketua prodi membuat usulan penugasan sumber daya. Usulan penugasan sumber daya ini salah satunya berisi pembagian beban mengajar dosen untuk semester yang akan berjalan.

Pada penelitian ini, pembagian beban SKS mengajar dosen pengampu mata kuliah focus terkait sumber daya dosen. Proses bermula dari sumber daya dosen berupa pengisian matriks kompetensi dosen oleh semua dosen, rekapitulasi matriks kompetensi, sampai menghasilkan suatu dokumen pembagian beban mengajar yang merupakan proses yang menguras waktu dan pikiran pihak-pihak yang terlibat. Kondisi ketua Prodi juga disibukkan dengan banyak kegiatan awal semester yang

UNITEX Vol 11 No.2 Juli - Desember 2018 | p-ISSN 2089-3957 | e-ISSN 2580-2585 
lain. Sementara itu, pengumuman pembagian beban SKS mengajar dosen diharapkan dilakukan seawal mungkin sehingga para dosen dapat mempersiapkan materi perkuliahan dengan baik.

Penelitian sebelumnya menyatakan algoritma genetika merupakan pilihan yang tepat untuk optimasi penjadwalan. Pada penelitiaanya tentang Sistem Pendukung Keputusan (SPK) pembagian beban mengajar dosen dengan metode algoritma genetika menghasilkan distribusi beban mengajar secara otomatis berdasarkan input matriks kompetensi dosen. Sehingga pembagian beban mengajar dosen dapat merata dengan baik (Janah and Brayudi, 2016). Salah satu metode yang dapat dipakai untuk mengatasi permasalahan penjadwalan yaitu dengan pendekatan metaheuristik. Berbagai macam yang tergolong dalam metode metaheuristik salah satu diantaranya yaitu algoritma genetika(Widodo, Santoso and Siswanto, 2014). Sebelumnya, penelitian Bahri (2012) telah membangun suatu sistem pendukung keputusan pembagian beban kerja dosen yang meliputi kegiatan pengajaran, penelitian dan pengabdian masyarakat. Metode yang digunakan yaitu logika fuzzy dimana metode ini digunakan untuk menentukan nilai bobot untuk setiap atribut kemudian dilakukan pemeringkatan untuk menyeleksi alternatif yang diberikan. Variabel masukan dari perangkat lunak ini adalah kegiatan penelitian dan kegiatan pengabdian pada masyarakat, kegiatan penunjang, dan kegiatan utama lainnya. Keluaran dari perangkat lunak yang dibuat adalah jumlah beban kerja minimal dan maksimal yang direkomendasikan dalam satuan SKS.

Berdasarkan permasalahan yang dipaparkan tersebut, maka penulis mengusulkan membuat sebuah aplikasi pembagian beban SKS mengajar dosen pengampu mata kuliah berbasis web dengan metode algoritma genetika yang diharapkan dapat membantu mempercepat tugas Ketua Prodi dengan menyediakan fasilitas distribusi beban mengajar dosen secara otomatis. Data dosen dan mata kuliah yang digunakan dalam penelitian ini dibatasi pada data belajar mengajar pada Jurusan Teknik Informatika Sekolah Tinggi Teknologi Dumai.

\section{Metode Penelitian}

Metode pengembangan yang digunakan pada penelitian ini yaitu metode pengembangan berbasis prototipe dengan tahapan-tahapan sebagai berikut: Perencanaan sistem (Systems Planning). Pada tahapan ini peneliti melakukan pengumpulan data dengan melalui studi literatur, dan pengambilan data kurikulum, mata kuliah, tenaga pendidik, ruangan yang ada di akademik STT Dumai.

1. Analisis sistem (Systems Analysis)

UNITEX Vol 11 No.2 Juli - Desember 2018 | p-ISSN 2089-3957 | e-ISSN 2580-2585 
Setelah melakukan perencanaan sistem maka kemudian dilakukan kegiatan analisis sistem. Pada tahapan ini, akan di analisa tentang sistem yang ada dan sistem yang akan dikembangkan, menganalisa kebutuhan pengguna serta menganalisa kebutuhan sistem itu sendiri. Dalam tahap analisa sistem terdapat langkah-langkah dasar yang harus dilakukan oleh peneliti, yaitu:

a. Identify (mengidentifikasi masalah)

Menemukan penyebab permasalahan yang timbul selama ini, misalnya penumpukan barang yang sudah kadaluarsa karena kurangnya pengecekan ataupun terjadi karena tidak terdeteksi dari awal dengan baik.

b. Understand (memahami kerja dari sistem yang ada)

Memahami sistem yang ada diperlukan untuk mengetahui bagaimana proses-proses yang terjadi dalam sistem yang digunakan selama ini.

c. Analyze (menganalisis sistem)

Menganalisa permasalahan-permasalahan yang terjadi pada sistem yang ada selama ini dan mencarikan alternatif solusi yang dapat digunakan untuk memecahkan permasalahan tersebut.

d. Report (membuat laporan hasil analisis)

Setelah semua tahapan analisis diatas dilakukan, langkah terakhir adalah membuat laporan yang merupakan rangkuman hasil kegiatan setiap proses sebelumnya.

2. Desain Sistem (Systems Design)

Dalam tahap desain sistem, secara global, peneliti merancang suatu sistem dengan mengimplementasikan algoritma genetika untuk digunakan pada pembuatan aplikasi penentuan beban SKS mengajar dosen pengampu mata kuliah dan merancang basis data yang dibutuhkan.

3. Revisi Sistem (Systems Revision)

Hasil dari desain sistem adalah sistem diatas kertas. Untuk dapat diimplementasikan, maka komponen-komponen sistem secara fisik perlu dilengkapi. Komponen fisik sistem ini adalah komponen teknologi yang dapat berupa perangkat keras maupun lunak. Karena banyaknya alternatif teknologi yang tersedia maupun penyedia maka perlu dilakukan revisi pada program yang telah didesain. Tahap revisi sistem merupakan tahap untuk memilih perangkat keras dan perangkat lunak untuk mendukung sistem yang akan dikembangkan nantinya serta perancangannya.

4. Implementasi Sistem (Systems Implementation)

Selanjutnya pada tahap pengimplementasian, tahap ini akan melibatkan pelatihan bagi pemakai untuk mengendalikan sistem. Selain itu, juga perlu merencanakan konversi perlahan dari sistem lama ke sistem baru jika itu

UNITEX Vol 11 No.2 Juli - Desember 2018 | p-ISSN 2089-3957 | e-ISSN 2580-2585 
diperlukan. Proses ini mencakup perubahan file-file dari format lama ke format baru atau membangun suatu basis data baru, dan instalasi peralatan. Kerja sistem biasanya dilakukan berulang-ulang. Bila menemukan masalah maka bisa kembali ketahap sebelumnya dan memodifkasi pekerjaannya ditahap tersebut. Cakupan dari tahap implementasi ini yaitu, pengembangan perangkat lunak, perancangan perangkat lunak, pengujian dan pelatihan.

5. Integrasi Sistem (Systems Integrasion)

Ditahap akhir dari pengembangan sistem, bahwa sistem tersebut harus dapat diintegrasikan dengan sistem yang sudah ada dan sistem dapat dipertahankan atau dirawat. Pada tahap integrasi diperlukan integrasi data dosen pengampu mata kuliah beserta komponen-komponen lainnya yang terkait. Ini berarti bahwa program komputer harus dimodifikasi dan dijaga supaya tetap terpakai. Namun dalam pengembangan sistem ini, pengembangan sistem hanya dilakukan hingga tahap implementasi sistem. Perawatan sistem berada diluar batasan pengembangan sistem.

Tahapan pengembangan sistem dapat dilihat pada Gambar 1.

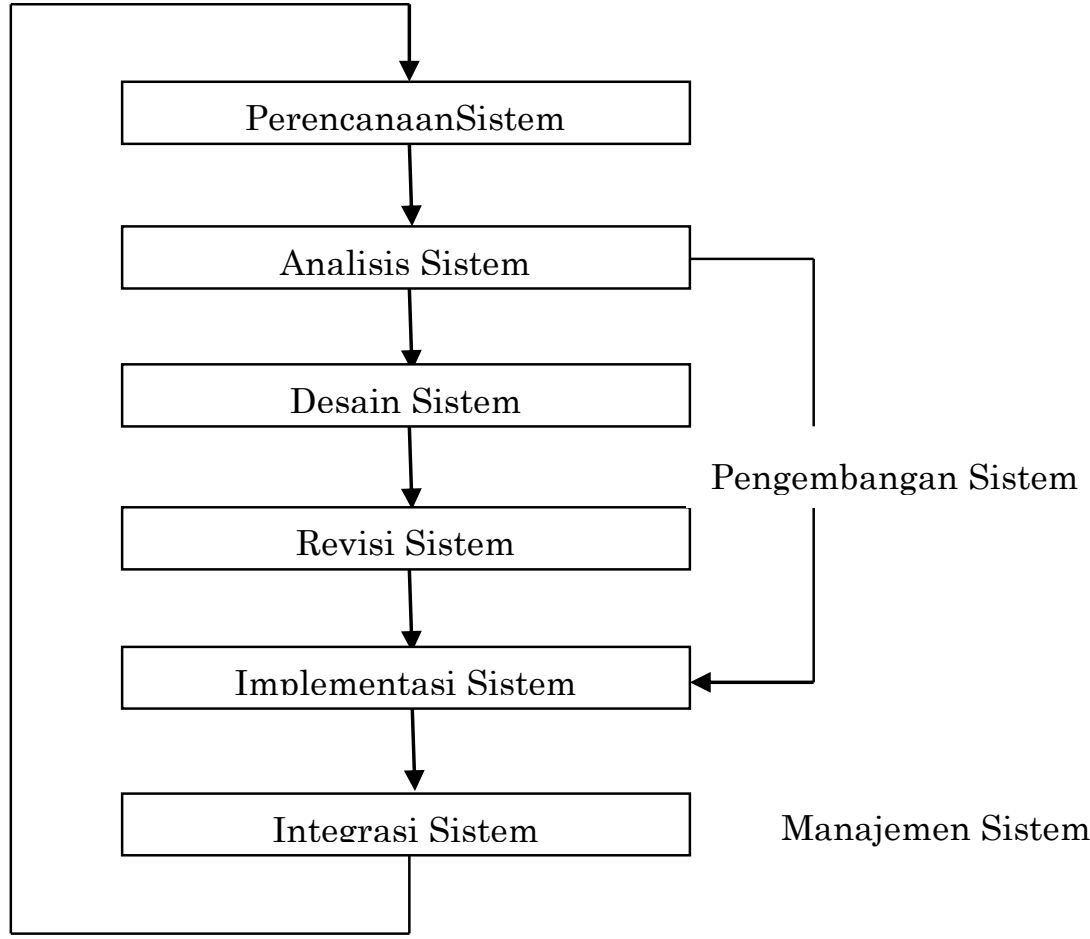

Gambar 1. Tahapan pengembangan sistem

UNITEX Vol 11 No.2 Juli - Desember 2018 | p-ISSN 2089-3957 | e-ISSN 2580-2585 
Rancangan penelitian yang akan dilakukan menggunakan beberapa komponen yang terkait yaitu Dosen pengampu,mata kuliah, ruang dan waktu dengan sejumlah batasan-batasan tertentu, dimana batasan-batasan tersebut ada yang harus dipenuhi atau tidak boleh dilanggar. Untuk selanjutnya diproses dengan metode algoritma genetika dan menghasilkan ketentuan beban SKS mengajar Dosen pengampu mata kuliah yang optimal.

\section{Hasil dan Pembahasan}

Berdasarkan tugas dalam pelaksanaan belajar mengajar terdapat 2 peran Dosen yaitu:

1. Dosen Pengampu, merupakan Dosen yang mempersiapkan program pengajaran untuk sebuah mata kuliah pada sebuah semester. Dosen pengampu betugas menyiapkan Rencana Pembelajaran Semester (RPS), Satuan Acara Perkuliahan (SAP) dan Bahan Ajar.

2. Dosen Pengajar, merupakan Dosen yang memiliki tanggung jawab untuk menyampaikan materi ajar pada suatu mata kuliah tertentu.

Data yang digunakan pada penelitian ini yaitu data penjadwalan mata kuliah untuk semester ganjil tahun ajaran 2018/2019. Program studi Teknik Informatika memiliki 2 tipe kelas kuliah yaitu pagi dan sore. Waktu kuliah pagi dimulai dari pukul 08.00 - 13.00 sedangkan waktu kuliah sore dimulai dari pukul $16.30-21.30$. Aplikasi penentuan beban SKS mengajar dosen pengampu mata kuliah menggunakan algoritma genetika ini berubah-ubah sesuai periode waktu penjadwalan dan matakuliah yang dibuka ataupun digunakan. Sehingga, aplikasi harus dapat dijalankan dengan data input matakuliah yang berbeda-beda sesuai dengan kebutuhan. Berikut ini, di tampilkan data penjadwalan matakuliah untuk tahun ajaran semester ganjil tahun 2018-2019 pada program studi teknik informatika di kampus STT Dumai. Gambar 2 menunjukkan tampilan beranda dari aplikasi penjadwalan dosen. Pada gambar terlihat beberapa menu terdiri dari room, class, lecturer, and course. 


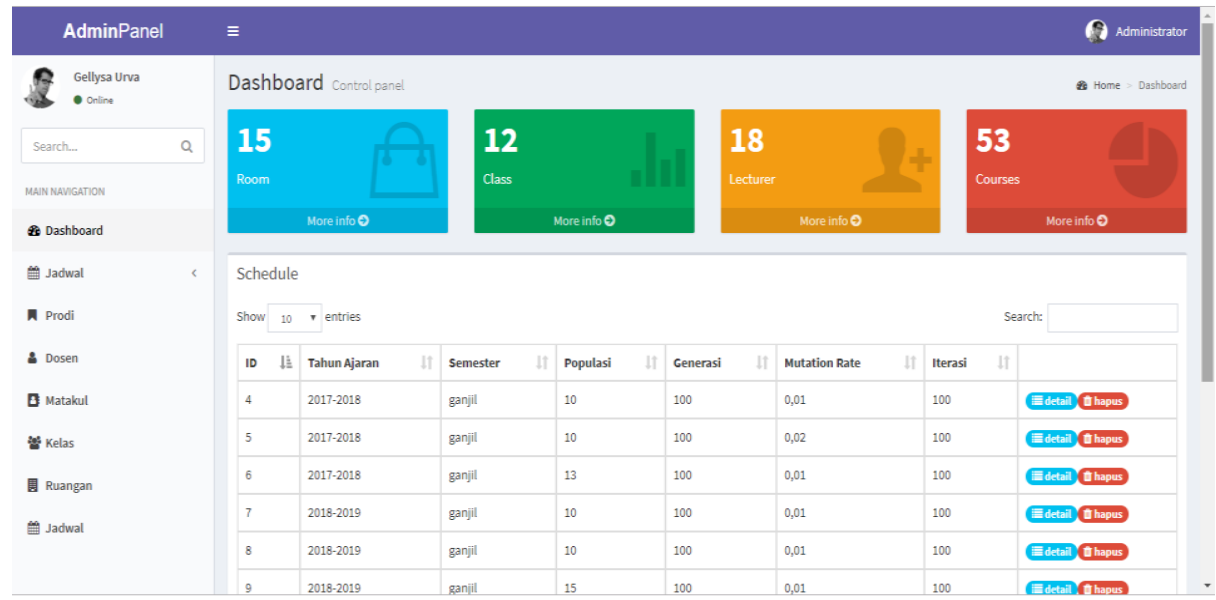

Gambar 2. Tampilan beranda aplikasi

Selanjutnya Gambar 3 menunjukkan daftar hari perkuliahan yang ada di prodi Teknik Informatika Sekolah Tinggi Teknologi Dumai.

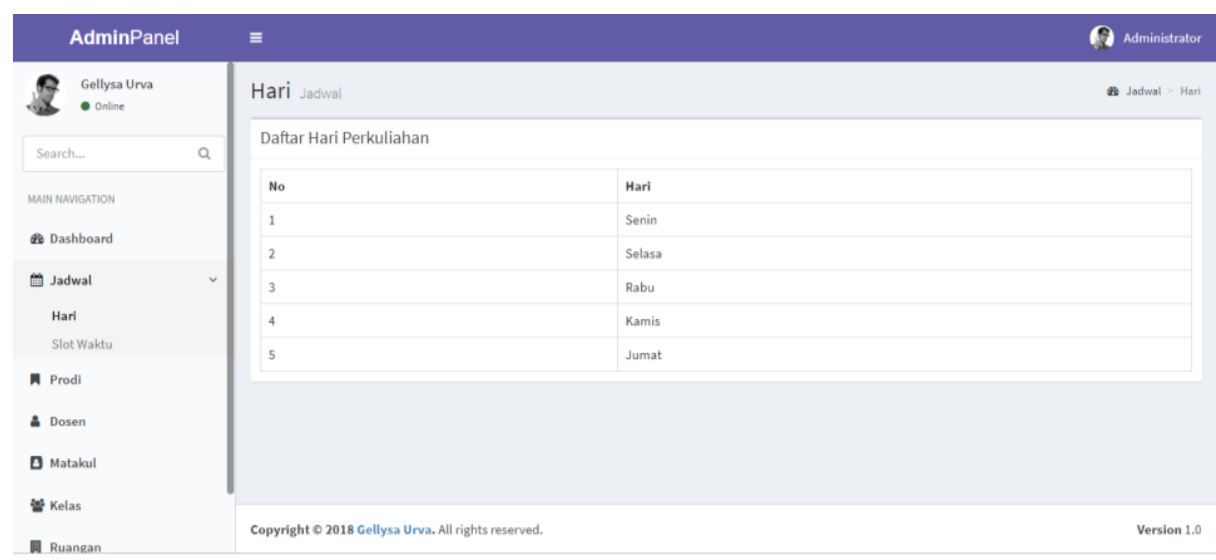

Gambar 3. Tampilan daftar hari perkuliahan

Pada Gambar 4 menunjukkan tampilan slot waktu perkuliahan yang digunakan di prodi Teknik Informatika Sekolah Tinggi Teknologi Dumai yang terdiri dari perkuliahan pagi dan sore. 


\begin{tabular}{|c|c|c|c|c|}
\hline AdminPanel & \multicolumn{3}{|l|}{$\equiv$} & Q Administrator \\
\hline 18 Gellysa Urva & \multicolumn{3}{|c|}{ Slot Waktu Jadwal } & $\$$ Jadwal = SlotWaktu \\
\hline Search.... & \multicolumn{4}{|c|}{ Daftar Slot Waktu Perkuliahan } \\
\hline \multirow{2}{*}{ MAIN NAVIGATION } & No & Mulai & Berakhir & \\
\hline & 1 & 08:00:00 & 08:50:00 & \\
\hline Dashboard & 2 & 08:50:00 & 09:40:00 & \\
\hline Jadwal & 3 & 09:40:00 & $10: 30: 00$ & \\
\hline Hari & 4 & 10:30:00 & 11:20:00 & \\
\hline Slot Waktu & 5 & 11:20:00 & $12: 10: 00$ & \\
\hline Prodi & 6 & 12:10:00 & 13:00:00 & \\
\hline - Dosen & 7 & 16:30:00 & $17: 20: 00$ & \\
\hline \multirow[t]{2}{*}{ D Matakul } & 8 & 17:20:00 & $18: 10: 00$ & \\
\hline & 9 & 18:10:00 & 19:00:00 & \\
\hline Kelas & 10 & 19:00:00 & 19:50:00 & \\
\hline
\end{tabular}

Gambar 4. Tampilan slot waktu perkuliahan

Pada aplikasi terdapat data dosen yang mengajar di program studi Teknik Informatika, dimana data dapat diedit atau dihapus sesuai dengan kebutuhan dan informasi terbaru. Dapat dilihat pada Gambar 5.

\begin{tabular}{|c|c|c|c|c|c|}
\hline AdminPan & \multicolumn{4}{|l|}{$\equiv$} & (2) Administrator \\
\hline G. Gellysa Urva & \multicolumn{4}{|c|}{ Dosen Home } & 20 Home = Dosen \\
\hline Search... & \multicolumn{4}{|c|}{ Daftar Dosen } & t tambah \\
\hline \multirow{2}{*}{ MAIN NAVIGATION } & No & NIDN & Nama & & \\
\hline & 1 & 1015079001 & Adelia Alfama Zamista, M.Pd & editt hapus & \\
\hline Dashboard & 2 & 1305108401 & AMIROEL SYARIEF, M.H & editt hapus & \\
\hline 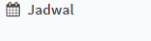 & 3 & 1022028103 & Ari Sellyana, S.T., M.Kom & editt hapus & \\
\hline n Prodi & 4 & 1020078801 & Desyanti, M.Kom & editt hapus & \\
\hline - Dosen & 5 & 1024058902 & Devit Satria, M.PdT & editt hapus & \\
\hline \multirow{2}{*}{ D Matakul } & 6 & $x x x x x x x x x 1$ & EMI YUZAR, M.Si & editi hapus & \\
\hline & 7 & 1029089001 & Erna Alimudin, S.T., M.Eng & editt hapus & \\
\hline Ad Kelas & 8 & 1014029101 & Febrina Sari, M.Kom & editi hapus & \\
\hline \multirow[t]{2}{*}{ 娄 Ruangan } & 9 & 1025069001 & Gellysa Urva, S.T., M.Kom & edit hapus & \\
\hline & 10 & $x x x x x x x x x=2$ & INDRA GUNAWAN, M.Ag & editt hapus & \\
\hline
\end{tabular}

Gambar 5. Tampilan data dosen

Selain pendataan hari dan waktu kuliah serta dosen pengampu mata kuliah, selanjutnya mendata mata kuliah berdasarkan kurikulum prodi Teknik Informatika Sekolah Tinggi Teknologi Dumai. Pada menu data mata kuliah juga terdapat edit dan hapus serta tambah untuk upgrade data mata kuliah. Pada Gambar 6 dapat dilihat data mata kuliah. 


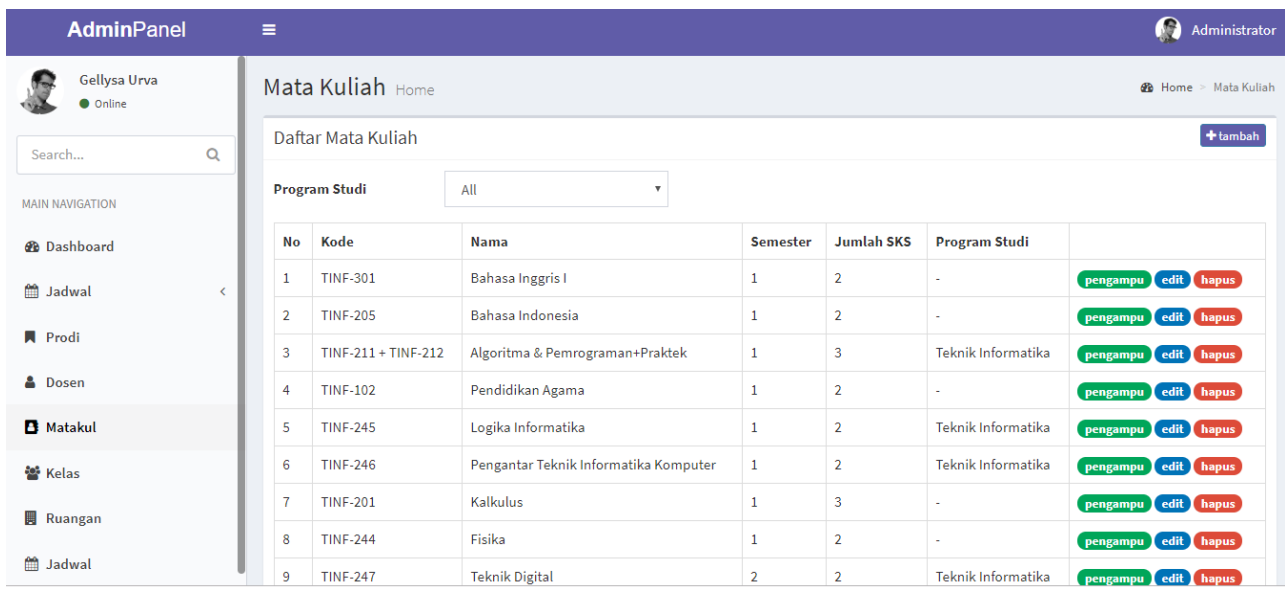

Gambar 6. Tampilan data mata kuliah

Selanjutnya, Gambar 7 menampilkan data ruangan untuk perkuliahan yang digunakan di program studi Teknik Informatika Sekolah Tinggi Teknologi Dumai.

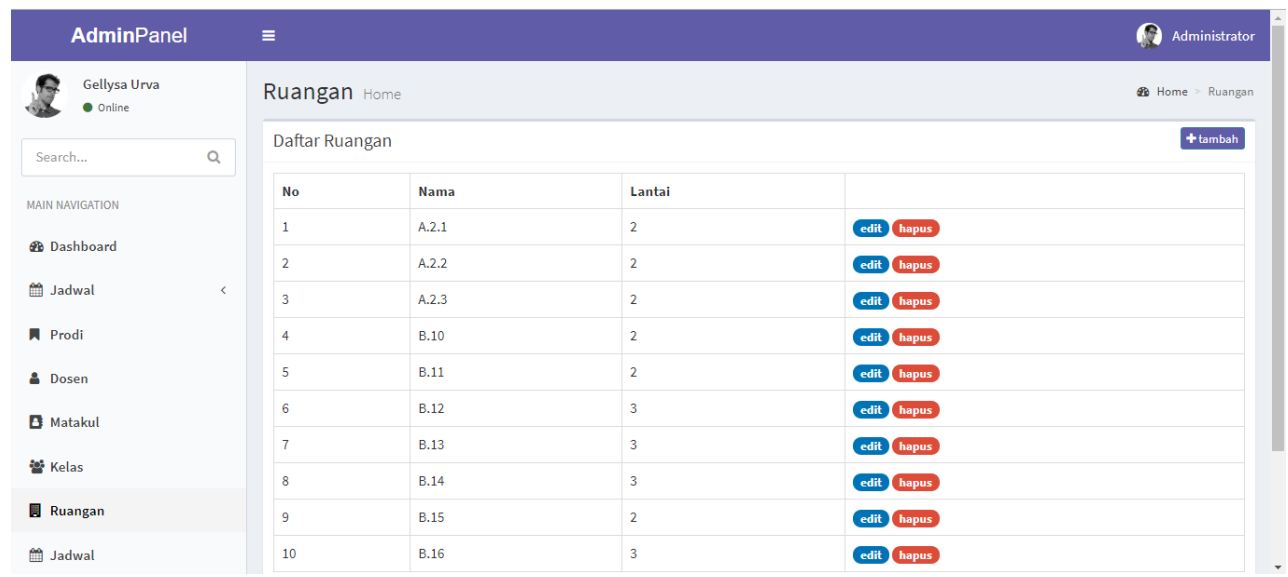

Gambar 7. Tampilan ruangan perkuliahan

Gambar 8 menunjukkan proses penentuan pembagian beban SKS mengajar dosen pengampu mata kuliah. 


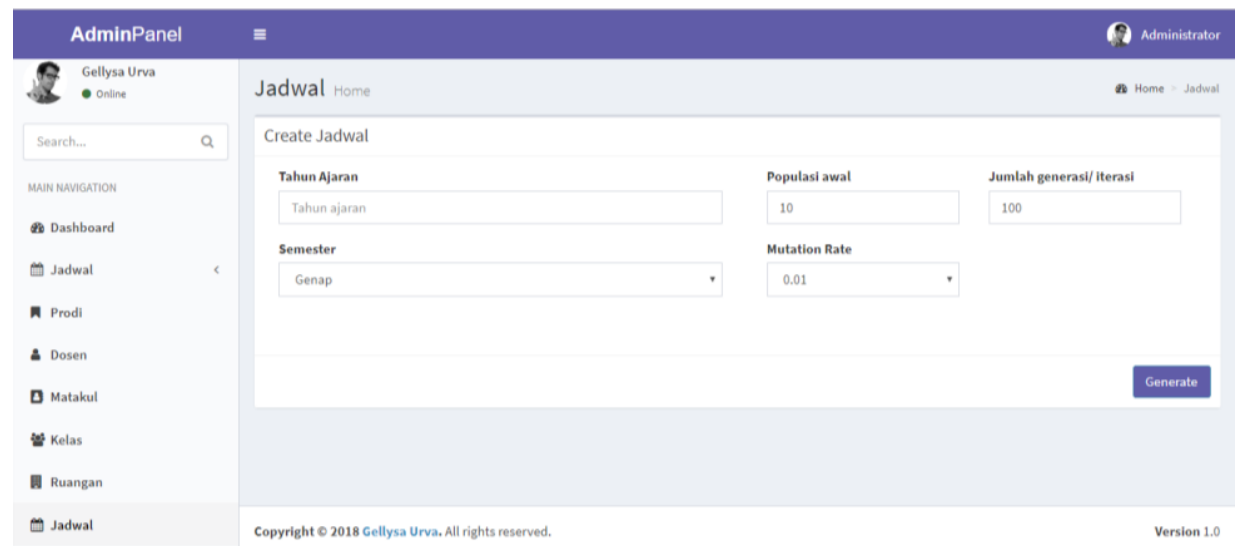

Gambar 8. Tampilan proses penentuan sks mengajar

\section{Kesimpulan}

Aplikasi penentuan beban SKS mengajar Dosen Pengampu Mata Kuliah ini dapat lebih optimal membantu mendistribusikan pembagian beban SKS mengajar secara merata dan otomatis.

\section{Daftar Pustaka}

Janah, N. Z. and Brayudi, I. (2016) 'Sistem Pendukung Keputusan Pembagian Beban Mengajar Dosen Dengan Metode Algoritma Genetika Studi Kasus : Politeknik Negeri Batam', pp. 6-7.

Widodo, D. S., Santoso, P. B. and Siswanto, E. (2014) 'Pendekatan Algoritma Cross Entropy - Genetic Algorithm Untuk Menurunkan Makespan Pada Penjadwalan Flow Shop', 2(1), pp. 41-49.

Bahri, Syamsul. 2012. "Rancang Bangun Sistem Pendukung Keputusan Pembagian Beban Kerja Dosen (Bkd) Berbasis Logika Fuzzy". Lhokseumawe: Jurusan Teknik Elektro Politeknik Negeri Lhokseumawe.

Anita., Q, 2014, Penjadwalan Ujian akhir semester dengan Algoritma Genetika studi kasus jurusan teknik Informatika Unesa, Jurnal Manajemen Informatika. Volume 03 Nomor 02 Tahun 2014, 33 - 38.

UNITEX Vol 11 No.2 Juli - Desember 2018 | p-ISSN 2089-3957 | e-ISSN 2580-2585 
Devi, OC, Mahmudy, WF \& Setiawan, BD, 2015, Penerapan Algoritma Genetika Untuk Penjadwalan Asisten Praktikum, Jurnal Mahasiswa PTIIK Universitas Brawijaya, vol. 5, no. 11.

Tsai, M. W., Hong, T. P., \& Lin, W. T. (2015). A Two Dimensional Genetic Algorithm and Its Application to Aircraft Scheduling Problem. Hindawi Publishing Corporation Mathematical Problems in Engineering.

Dian,SW., Purnomo, BS.,\& Eko, S., 2014, Pendekatan Algoritma Cross EntropyGenetic Algorithm Untuk Menurunkan Makespan Pada Penjadwalan Flow Shop, Jurnal JEMIS Vol. 2 No. 1, Hal. 41 